Available online at GSC Online Press Directory

GSC Biological and Pharmaceutical Sciences

e-ISSN: 2581-3250, CODEN (USA): GBPSC2

Journal homepage: https://www.gsconlinepress.com/journals/gscbps

(RESEARCH ARTICLE)

\title{
Cyanophytes of the Joal-Fadiouth Lagoon (Senegal)
}

\author{
Gueye Madiop *, Ba Ngansoumana, Ngom Ablaye, Mbaye Mame Samba and Noba Kandioura \\ Laboratoire de Botanique - Biodiversité, Département de Biologie Végétale, Faculté des Sciences et Techniques, Université \\ Cheikh Anta Diop, BP 5005, Dakar-Fann, Sénégal.
}

Publication history: Received on 04 July 2020; revised on 12 July 2020; accepted on 15 July 2020

Article DOI: https://doi.org/10.30574/gscbps.2020.12.1.0211

\begin{abstract}
Despite the diversity of estuaries and lagoons and the importance of mangroves in Senegal, microphytes (cyanophytes and microalgae) have not yet been studied there. The objective of this study is to describe and identify the cyanophytes of the Joal-Fadiouth Lagoon and to determine their taxonomic composition. The samples were collected between March and June 2013. The results show that 12 species of cyanophytes belonging to 10 genera and distributed into 7 families, 3 orders and one class were inventoried. These 12 species are new for the microflora of the Joal-Fadiouth Lagoon.
\end{abstract}

Keywords: Cyanophytes; Taxonomic composition; Joal-Fadiouth; Lagoon; Senegal.

\section{Introduction}

Senegal has a littoral of around $700 \mathrm{~km}$ consisting mainly of sandy coasts, rocky coasts, mangrove estuaries [1]. Mangroves occupy downstream parts of estuaries, lagoons, deltas and main river mouths and develop in the tidal fluctuation zone. Their area in Senegal is $1,287 \mathrm{~km}^{2}$ [2]. These mangroves are among the most productive ecosystems in the world. They house specifics animals (oysters, barnacles, arches, crabs) and also serve as refuge for birds, juvenile fish and shrimp, thus contributing significantly to the effective functioning of fish communities on the continental shelf. Despite the diversity of estuaries and lagoons and the importance of mangroves composed of six very characteristic plant species (Rhizophora racemosa, $R$. harisonnii, $R$. mangle, Avicennia africana, Laguncularia racemosa and Conocarpus erectus) in Senegal, microphytes (cyanophytes and microalgae) are not yet studied there. This study aims to describe, identify and determine the taxonomic composition of the cyanophytes of Joal-Fadiouth Lagoon which can play, with microalgae, an essential role in the regeneration of the fishery resource of Joal (Mbour), one of the most important docks in Senegal.

\section{Material and methods}

\subsection{Presentation of Joal-Fadiouth Lagoon}

The Lagoon is located in the Commune of Joal-Fadiouth $\left(16^{\circ} 49^{\prime} 60 \mathrm{~W}, 14^{\circ} 10^{\prime} 0 \mathrm{~N}\right)$ at the end of the "Petite Côte", $114 \mathrm{~km}$ South East of Dakar (Figure 1). The Commune brings two villages, Joal (5,023 ha), established on the littoral, and Fadiouth (12 ha), an artificial island made up of shell mounds. $4 \mathrm{~km}$ wide and $10 \mathrm{~km}$ long from North to South, the JoalFadiouth Lagoon is the largest lagoon of the "Petite Côte" and is limited to the West by Atlantic Ocean; it is considerably ramified by marigots and bolons and consisted of sandy-silty islands where a large mangrove forest develops.

The Lagoon undergoes permanent marine action and continental influence which is suitable for the irregularities of the climate. It marks the southern limit of the "Petite Côte" [3]. The area has two contrasting seasons [4]; a dry season (November-June) where temperatures are often high, $27^{\circ} \mathrm{C}$, and a hot and humid season with low rainfall (525 mm on

\footnotetext{
${ }^{*}$ Corresponding author: Gueye Madiop
}

Copyright (C) 2020 Author(s) retain the copyright of this article. This article is published under the terms of the Creative Commons Attribution Liscense 4.0. 
average). The main plant species identified in Joal-Fadiouth Lagoon are: Rhizophora racemosa, Rhizophora mangle (Rhizophoraceae), Avicennia africana (Verbenaceae), Conocarpus erectus and Laguncalaria racemosa (Combretaceae).

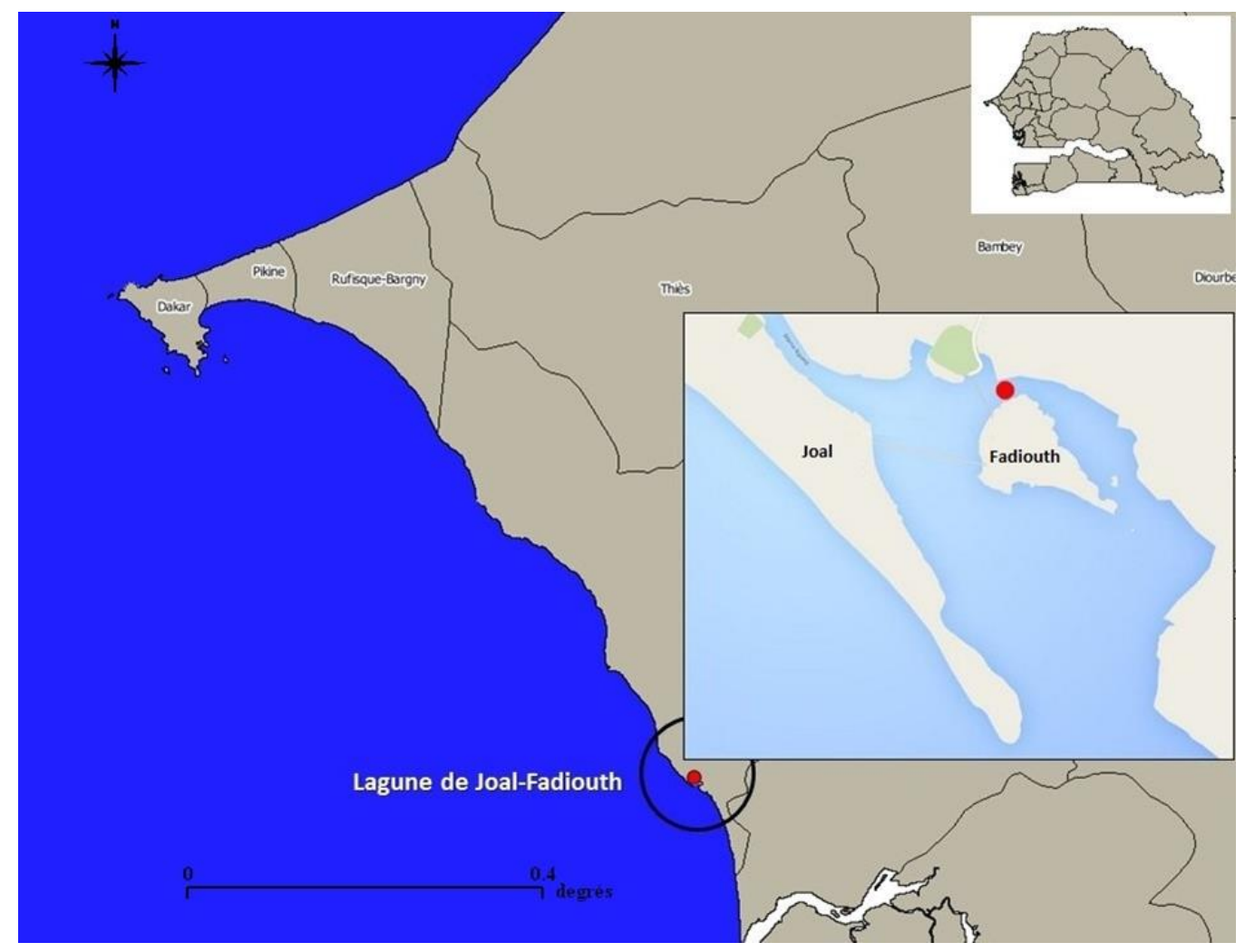

Figure 1 Location of the Joal-Fadiouth Lagoon

\subsection{Sampling methods}

The samples were collected between March and June 2013 in an oyster production area, between the village of Fadiouth and the cemetery, at $14^{\circ} 09^{\prime} 20.2^{\prime \prime} \mathrm{N}$ and $016^{\circ} 49^{\prime} 26.2^{\prime \prime} \mathrm{W}$, using a plankton net and by scraping glass supports placed on the vase. The six samples collected were immediatly fixed with formalin $4 \%$.

\subsection{Observation and identification of taxa}

The observations were made using a Motic Digital Microscope equipped with a digital camera. The dimensions of each examined taxon was measured in microns $(\mu \mathrm{m})$. From the description, photos, drawings and dimensions, identification of the taxa was made possible by comparison of the data with previous works.

The systematic arrangement of the list was made by according to $[5,6,7,8]$.

\section{Results and discussion}

\subsection{Description and identification of taxa}

Phylum: Cyanophyta

Class: Cyanophyceae

Order: Chroococcales

Family: Chroococcaceae 


\subsubsection{Chroococcus minutus (Kützing) Nägeli (Figure 2A)}

Colony of two granulated subspheric cells ( $8 \mu \mathrm{m}$ diameter, 9-10 $\mu \mathrm{m}$ length); green-yellow color. Cells have the same characteristics as those described by [9].

\subsubsection{Chroococcus $s p$ (Figure $2 B$ )}

Colony of several hemispherical cells (7-11 $\mu$ m diameter) with black granulations.

Family: Xenococcaceae

\subsubsection{Myxosarcina sp (Figure 2C)}

Blackish blue thallus (diameter $27 \mu \mathrm{m}$ ) formed of cells (diameter 2-3 $\mu \mathrm{m}$ ) not completely spherical (sometimes polygonal), grouped by 4 or more in the form of glomeruli.

Family: Synechococcaceae

\subsubsection{Johannesbaptistia pellucida (Dickie) Taylor and Drouet (Figure 2D)}

Syn.: Hormospora pellucida Dickie

Linear cylindrical thallus, surrounded by hyaline mucilage (5-6 $\mu \mathrm{m}$ diameter); rectangular to discoid cells $(9-10 \mu \mathrm{m}$ diameter, about $4 \mu \mathrm{m}$ length) arranged in a single series. The species has the same characteristics as that described by [10].

Family: Merismopediaceae

\subsubsection{Aphanocapsa marina Hansgirg (Figure 2E)}

Syn.: Microcystis marina (Hansgirg) Kosinnskaja

Amorphous colony formed of spherical cells (approximately $0.5 \mu \mathrm{m}$ in diameter) with granulations and densely grouped. The description corresponds to that given by [11].

\subsubsection{Merismopedia sp (Figure $2 F$ )}

Flat, tabular colony with cells very regularly arranged in vertical and horizontal rows. Hemispherical cells $(4 \mu \mathrm{m}$ diameter, 2.5-3 $\mu \mathrm{m}$ length) green with pseudovacuoles.

Order: Oscillatoriales

Family: Pseudanabaenaceae

\subsubsection{Leptolyngbya cf. foveolarum (Rabenhorst ex Gomont) (Figure 2G)}

Syn.: Lyngbya foveolarum (Gom.) Hansg.

\section{Phormidium foveolarum Gomont}

Filament 1.5-2 $\mu \mathrm{m}$ in diameter. Green trichome, barely narrowed on the cross-walls. Cell length approximately $1 \mu \mathrm{m}$. This specimen has the same description as that inventoried by [12].

\subsubsection{Pseudanabaena catenata Lauterb. (Figure $2 \mathrm{H}$ )}

Green trichome with apparently non-contiguous cylindrical cells (1.5 $\mu$ m diameter, 6-7 $\mu$ m length).

\subsubsection{Pseudanabaena sp (Figure 2I)}

Green trichome with apparently non-contiguous barrel cells (1 $\mu$ m diameter, 1-1.5 $\mu \mathrm{m}$ length).

Family: Oscillatoriaceae 


\subsubsection{Lyngbya semiplena J. Agardh ex Gomont (Figure 2J)}

Filament with firm sheath; slightly constricted trichome. Rectangular cells ( $9 \mu \mathrm{m}$ diameter, $2-3 \mu \mathrm{m}$ length) provided with many blackish granulations, more numerous at the cross-walls. The description of the species corresponds to that of $[13,14]$.

\subsubsection{Oscillatoria sp (Figure $2 K$ )}

Trichome straight, green-yellow, with many black and white granulations; slight narrowing at the cross-walls. Rectangular cells ( $9 \mu \mathrm{m}$ diameter, 2-3 $\mu$ m length).

Order: Nostocales

Family: Rivulariaceae

\subsubsection{Calothrix sp (Figure $2 L$ )}

Filament with tapered apex and triangular basal heterocyst (6-7 $\mu \mathrm{m}$ diameter, length $6 \mu \mathrm{m})$. Brown-red trichome with granulations. Rectangular cells (11-12 $\mu \mathrm{m}$ base diameter, 2-3 $\mu \mathrm{m}$ length).
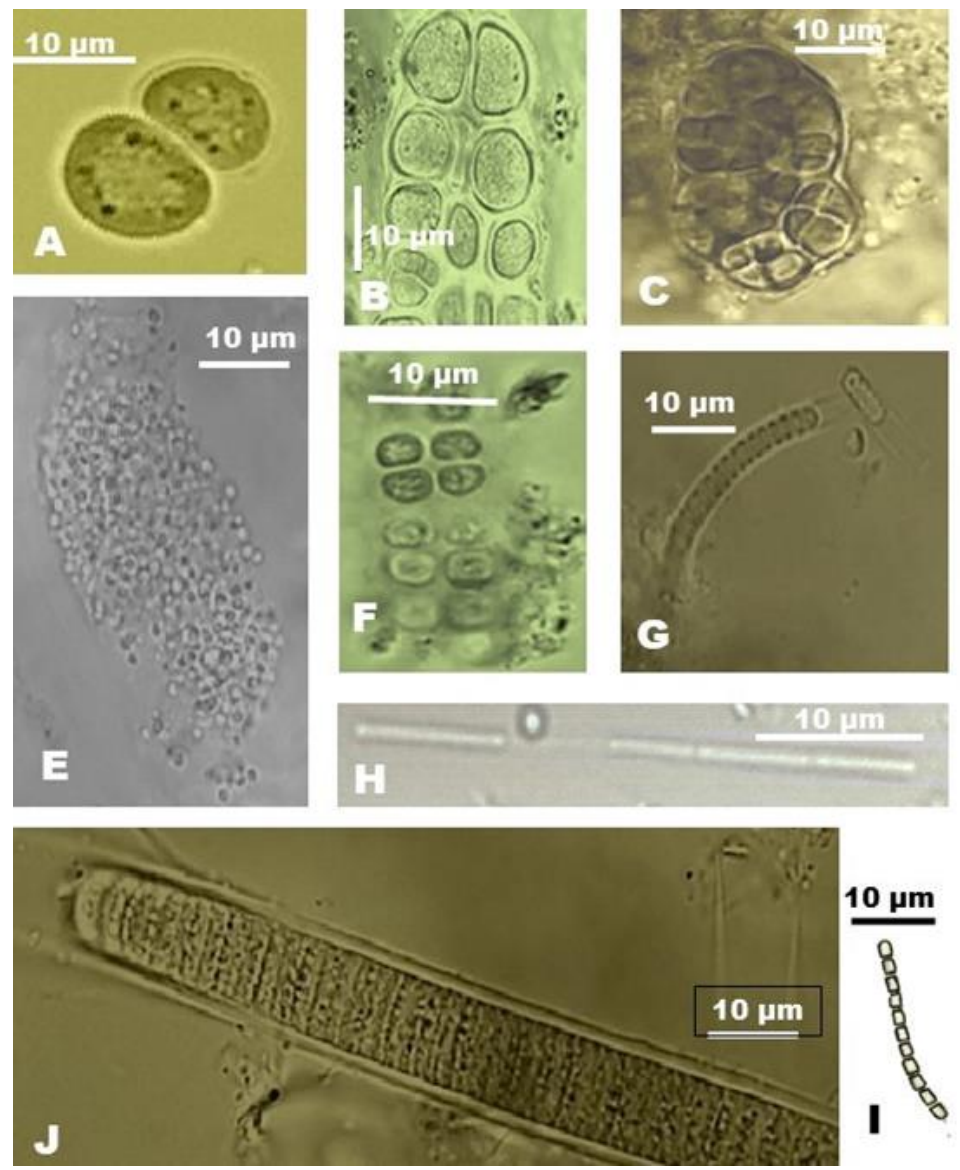
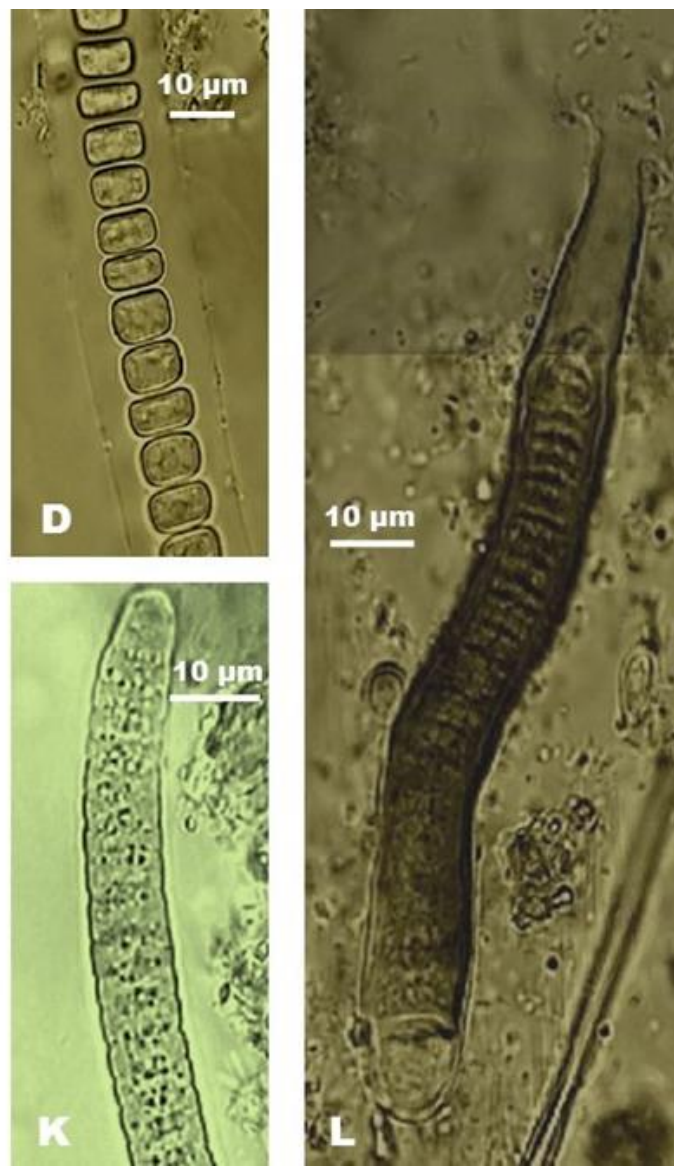

Figure 2 A : Chroococcus minutus ; B : Chroococcus sp ; C : Myxosarcina sp ; D : Johannesbaptistia pellucida; E : Aphanocapsa marina ; F: Merismopedia sp ; G : Leptolyngbya cf. foveolarum ; H : Pseudanabaena catenata ; I : Pseudanabaena sp ; J : Lyngbya semiplena. ; K: Oscillatoria sp; L: Calothrix sp.

\subsection{Taxonomic composition}

12 species of cyanophytes, belonging to 10 genera and divided into 7 families 3 orders and one class, have been inventoried in the Joal-Fadiouth Lagoon. 
The Pseudanabaenaceae is the most representative family with three species. It is followed by Chroococaceae, Merismopediaceae and Oscillatoriaceae, each represented by two species. The other families each have only one species. Only the genus Pseudanabaena has two species.

The great diversity of cyanophytes in this environment could be because they support large amplitudes of salinity and include a large proportion of very euryhaline species [15]. The results also showed a greater representativity of nonheterocystous species. The heterocystous species, capable of fixing atmospheric nitrogen when the environment is poor, are represented by only one species (Calothrix $s p$ ). This could be because the samples were taken where the population discharged wastewater; which increases the quantity of nitrogen in these waters. This hypothesis was put forward by [16] for whom, the high representativity of these cyanophytes could be influenced by the greater availability of nutrients, particularly nitrate and phosphate, due to the discharge of wastewater.

\section{Conclusion}

This study contributed to a better knowledge of the cyanophytes of the Joal-Fadiouth Lagoon with the inventory of 12 species belonging to 10 genera and divided into 7 families and 3 orders. These 12 species are new for the microflora of the Lagoon.

\section{Compliance with ethical standards}

\section{Disclosure of conflict of interest}

The authors declare no conflict of interest.

\section{References}

[1] Diaw AT. (1984). Morphometry of the Senegalese and Gambian littoral. African Notes, Dakar, 183, 58-63.

[2] UNEP. (2007). Mangroves of Western and Central Africa. UNEP-Regional Seas Programme/UNEP-WCMC, 92.

[3] Turmine V. (2000). The dynamics of the coast between Mbour and Joal (Petite Côte-Senegal). Master's thesis, Denis Dinerot University, Paris, 249.

[4] Faye G. (2010). The impacts of economic activities on the dynamics of the Petite Côte, from Hann Bay to Joal in Senegal. RGLL, 8, 119-130.

[5] Komarek J and Anagnostidis K. (1989). Modern approach to the classification system of cyanophytes 2Nostocales. Algological Studies, 56, 247-345.

[6] Komarek J and Anagnostidis K., (1998). Cyanoprokaryota. 1st part Chroococcales. In G., Gärtner, H., Heynig and D. Mollenhauer (ed.), Freshwater Flora of Milleleuropa, 19/1. Fisher, Stuttgart-Jena, Germany, 548.

[7] Komarek J and Anagnostidis K. (2005). Cyanoprokaryota. 2. Teil Oscillatoriales. In G., Gärtner, H., Heynig and D. Mollenhauer (ed.), Süßwasserflora von Milleleuropa, 19/2. Fisher, Stuttgart-Jena, Germany, 759.

[8] Anagostidis K and Komarek J. (1990). Modern approach to the classification system of Cyanophytes, 5, Stigonematales. Algo. Studies, 59, 1-73.

[9] John DM, Whitton BA and Brook AJ. (2002).The freshwater algal flora of the British Isles: an identification guide to freshwater and terrestrial algae. Cambridge University Press, 1, 702.

[10] McGregor GB. (2013). Freshwater Cyanobacteria of North-Eastern Australia: 2. Chroococcales. Phytotaxa, 133 (1), 130.

[11] D'hont D and Coppejans E. (1988). Cyanophyceae from the northern coasts of France and Belgium. Taurus. Soc. Roy. Bot. Belg, 121, 35-54.

[12] Matula J, Pietryka M, Richter D and Wojtuń B. (2007). Cyanoprokaryota and algae of Arctic terrestrial ecosystem in the Hornsund area, Spitsbergen. Pol. Polar Res, 28(4), 283-315.

[13] Branco LHZ, Moura AN, Silva AC and Bittencourt-Oliveira MC. (2003). Biodiversity and biogeographic considerations of cyanobacteria from a mangrove area in the state of Pernambuco, Brazil. Acta bot. bras, 17(4), 585-596. 
[14] Crispino LMB and Sant'Anna CL. (2006). Benthic marine cyanobacteria from coastal islands in the State of São Paulo. Brasil Revista Brasil. Bot, 29(4), 639-656.

[15] Iltis A. (1973). Algae from the natron waters of Kanem (Chad) 2nd part. Cah. O.R.S.T.O.M., ser. Hydrobiol, 7(1), 25-54.

[16] Sivakumar T, Narayani SS, Shankar T and Vijayabaskar P. (2012). Optimization of cultural conditions for exopolysaccharides production by Frateuria aurentia. International Journal of Applied Biology and Pharmaceutical Technology, 3(3), 133-143.

\section{How to cite this article}

Gueye M, Ba N, Ngom A, Mbaye MS and Noba K. (2020). Cyanophytes of the Joal-Fadiouth Lagoon (Senegal). GSC Biological and Pharmaceutical Sciences, 12(1), 156-161. 